\title{
HOLLÓSVÖLGYI MÁTÉ
}

\section{SZOCIALIZÁCIÓ ÉS DEVIANCIA AZ ERŐSZAKOS BŰNCSELEKMÉNYT ELKÖVETETTEK ISKOLAI ÉLETÚTJÁNAK VIZSGÁLATA EGY VIDÉKI FEGYHÁZ ÉS BÖRTÖNBEN}

\section{Bevezetés}

Az erőszakos bűncselekmények száma 2019-ben hazánkban javuló tendenciát mutat, számuk a 2019-es 3. negyedévi adatokat tekintve 5 éves tendenciát vizsgálva csökken (a Bűnügyi Statisztikai Rendszer adatai alapján). Ám a börtönök a mai napig teljes kihasználtsággal működnek, sőt 2008-ban két új magánbörtönt is átadtak, Tiszalökön és Szombathelyen, hogy a többi magyarországi börtön túlzsúfoltságát enyhíteni tudják. Sokáig nem volt egyetlen szakirodalom sem, ami a börtönök sajátos világáról szólt, és a börtönök is zárva voltak a civil emberek előtt, ez ma sem oldódott fel teljesen. Hiszen egy olyan speciális intézményről beszélhetünk, amelynek megvan a maga szervezeti kultúrája, amit egy oda érkező „kinti” ember nem nagyon ért meg.A kutatásom célja, hogy a deviáns viselkedésformák családi, iskolai és szocializációs hátterét feltárjam. Választ keresek arra, hogy vajon az iskolai végzettség és az elkövetett büncselekmények összefüggésben állnak-e. Meghatározó-e egy egyén életében egy iskolai kudarc?

\section{Történeti áttekintés}

A társadalmi együttélésben fontos, illetve a társadalmi együttélés alapfeltétele, hogy a társadalom tagjai betartsák a társadalmi normákat. A társadalmi normák írják elő az egyének számára, hogy egy-egy helyzetben hogyan viselkedjenek. Ha ezek a normák nem léteznének, akkor lehetetlenné válna a társadalmi együttélés. A normakövető magatartást nevezi a szakirodalom konform magatartásnak, míg azokat a magatartásokat, illetve embereket, amelyek, illetve akik ezeket a magatartásokat megszegik, deviánsnak. (Andorka, 1974) Tehát deviánsnak nevezzük az olyan viselkedéseket, amelyek eltérnek az adott társadalmi normáktól. Ez így leírva nagyon egyszerūnek tűnik, azonban a vizsgált tárgykör ennél sokkal bonyolultabb. A modern társadalmakban léteznek jogi normák, melyet az állam mint jogalkotó szerv hoz létre, ezek megszegése megtorlással jár, a kutatás témájához szorosan kötődve például jogerős börtönbüntetéssel. Honnan is ered a deviancia? Mikortól létezik ez a fogalom? Már az ókor nagy 
filozófusai is látták, hogy a normák a társadalmi rend biztosításának eszközei. A filozófusok és a társadalom tagjai is negatívnak tekintették azt a személyt, aki ezeket a normákat megszegi. Az ipari társadalmak létrejöttével egyre jobban foglalkoztatta a tudósokat a norma és a normaszegés viszonyrendszere. A normaszegés és az ezt követő társadalmi megtorlás vezetett többek között a szociológia kialakulásához is. A múlt században pszichológiai kutatások kimondták azt, hogy a normaszegő emberekben van egy közös tulajdonság, amely megkülönbözteti őket a társadalom normatisztelő tagjaitól. Ezt az álláspontot képviselte Lombroso a bűnözési elméletében. „A bünöző ember biológiailag különbözik a nem-bünözőtől, ebből ered pszichológiai különbözősége, mert a bünözőnek az antropológiai konstitúciója degenerált, a normálistól eltérö, és ez az eltérô jelleg öröklődik." (Andorka, 1974. 16. o.) Durkheim szerint a társadalmi integráció meggyengülésével úgynevezett anómia jön létre, és ennek következtében az emberek elveszítik biztonságérzetüket, és könnyen kerülnek olyan helyzetbe, melynek során életük folytatását értelmetlennek látják. Durkheim kutatásait más kutatások nem erősítették meg, de mégis nagy előrelépésnek tekinthetjük a téziseit. (Durkheim, 1982) A Chicagói Egyetem Szociológia Tanszéke Park és Burgess vezetésével összehasonlította a városrészekben előforduló normaszegő viselkedéseket, majd térképet készítettek a városban előforduló normaszegési arányról. Arra a következtetésre jutottak, hogy a városban van egy jellegzetes terület, amelyben kiugróan magas a bűnözők és az alkoholisták száma. Ez a szórakozóhelyek mellett elhelyezkedő olcsó motelek területe, melyben a viszonylag szegények és az emberi kapcsolatokból kiszakadt emberek élnek. Ez az elmélet megalapozza azt, hogy gyakoribb az olyan emberek körében a deviancia, akiknek alacsony a társadalmi státuszuk, illetve szegény környezetben és rossz anyagi körülmények között élnek. (Borbíró-Gönczöl et al. 2016) Robert Merton továbbfejlesztette Durkheim anómiaelméletét. Elméletének lényege, hogy a deviáns viselkedéseket az eltérő társadalmi és kulturális különbségek okozzák. A társadalom kijelöli az egyének számára az elérendő célokat, melyre az egyének tevékenysége irányul. Merton szerint akkor lesz egy egyén deviáns, amikor ezeket a kijelölt célokat nem képes a megengedett eszközökkel elérni. (Giddens, 2008) A későbbi személyiségfejlődéshez hozzájárulnak a társas kapcsolatok. Végül meg kell említenem a deviancia történeténél H. S. Becker nevét, aki azt állította, hogy nem attól válik valaki deviánssá, hogy bizonyos tetteket követ el, hanem attól, hogy a társadalom tagjai rásütik a "deviáns bélyegzőt". Ez az úgynevezett minősítési vagy labelling elmélet. (Giddens, 2008) Napjainkban a kriminológia mint önálló tudományág foglalkozik a bűnös emberekkel és a bűnözői magatartás kutatásával. „A kriminológiai a legáltalánosabb felfogás szerint elsősorban a büncselekmények halmazával, mint tömegjelenségekkel foglalkozik, de emellett szükségképpen vizsgálja az individuális bünelkövetést, a konkrét büncselekményeket, a tett, az elkövető és az áldozat milyenségét és az elkövetés körülményeit, mint a bünözés tömegjelenségének elemeit." (Vigh, 1998. 13. o.)

Ha bűnözésről beszélünk, és a bűnözés okait vizsgáljuk, nem szabad elfelejtkezni az iskola fontosságáról. Az iskolázottság és az iskolai végzettség a 
bűnözés gyakoriságát befolyásolja. Nagyon fontos egy egyén életében az, hogy milyen élményeket szerzett az iskolában, hiszen ez nagyban befolyásolja majd azt, hogy mennyire lesz motivált a tanulás iránt, illetve a későbbiek során milyen attitűdökkel fordul a társadalom felé. Az egész világra jellemző, hogy az iskolai végzettség és a bünelkövetés szoros kapcsolatban van egymással. Beszélhetünk fehérgalléros bűnözésről, mely a magasan kvalifikált személyek esetében van jelen, illetve erre a társadalmi rétegre jellemző, de a bűnözés jóval magasabb az aluliskolázottak körében. Tanulmányomban aluliskolázottnak tekintem azt, aki az alapfokú képzést nem fejezte be, vagy szakmai végzettséggel nem rendelkezik.

\begin{tabular}{|l|l|l|}
\hline MEGNEVEZÉS & Fö & $\%$ \\
\hline Analfabéta & 11 & 1,58 \\
\hline 8 általános iskolai végzettség alatt & 193 & 27,77 \\
\hline 8 általános iskolai végzettség & 268 & 38,57 \\
\hline 10 osztályt végzett & 16 & 2,3 \\
\hline Érettségi & 31 & 4,47 \\
\hline Szakmunkás & 144 & 20,71 \\
\hline Technikum & 4 & 0,57 \\
\hline Egyetem, föiskola & 2 & 0,28 \\
\hline Nem ismert & 26 & 3,75 \\
\hline ÖSSZESEN & 695 & 100,00 \\
\hline
\end{tabular}

1. táblázat

Pártfogoltak iskolai végzettsége 2018-ban Borsod-Abaúj-Zemplén megyében Forrás: Pártfogó Felügyelői Rendszer - A Borsod-Abaúj-Zemplén Megyei Kormányhivatal Pártfogó Felügyelői Osztályának OSAP statisztikája.

„Egy Hollandiában végzett longitudinális vizsgálat érdekes összefüggésekre mutatott rá - idézi: Weerman-Bijleveled, 2014 -: A kutatás elején 19.391 főt vizsgáltak meg 400 iskolából egészen 2010/11-es évig. Egy-egy egyedi kódot kaptak a kutatásban résztvevők, melynek segítségével követni tudták iskolai pályafutásukat (pl. ismételtek-e osztályt, abbahagyták-e az iskolát stb.). Ezt az adatbázist összekapcsolták 1996 és 2010 között a kriminálstatisztikai adatbázissal és arra a következtetésre jutottak, hogy az iskolaelhagyók, iskolai kudarccal rendelkezők nagyobb arányban követtek el büncselekményt, mint azok, akiknek hagyományos iskolai »útvonaluk« volt. E kutatás szerint a tulajdon elleni büncselekmények 56\%-a, a testi erőszakot elkövetők 32\%-a, droggal való visszaélők 11\%-a korai iskolaelhagyók közé számítottak. Mindezek alapján kimondhatjuk, hogy a képzettség szintje és a bünelkövetés között magas a korreláció, eröteljesen hatnak egymásra az alábbi tényezők: alacsony iskolai teljesítmény - korai iskolaelhagyás - kriminalizálódás." (Bodonyi, 24. 0.)

Ha iskolaelhagyásról és lemorzsolódásról beszélünk, nagyon fontos kiemelni a család szerepét ebben a folyamatban. (Vö. Oszlánczi és Simándi, 
2013) A szülő visszajelzése és nevelése alapján fogja a fiatal érdekesnek találni a tanulást. Fontos, hogy a fiatal az iskolában kapott értékeket mennyiben tudja összeegyeztetni a családban tapasztalt normákkal. Ha nagy a szakadék a kettő között, akkor ez könnyen vezethet iskolakerüléshez. Az oktatás akarva-akaratlanul a társadalmi egyenlőtlenségeket erősíti fel. A fiatalok kriminalizálódásához hozzájárul a tanulók közötti esélyegyenlőségek csökkenése, valamint az is, hogy a mai napig nincs a közoktatásban kidolgozva olyan stratégiarendszer, amely a hátránykezelés csökkentését hatékonyan célozza meg. (Hegedűs, 2014)

\section{A kutatás bemutatása}

Kutatásom helyszíne a Sátoraljaújhelyi Fegyház és Börtön volt, ahol 2018 szeptemberében készítettem el a mélyinterjúkat. A kutatás során strukturált interjú keretében beszélgettem minden fogvatartottal. A kutatásba bevont huszonöt elítélt kiválasztása teljesen véletlenszerűen zajlott. A kutatásba bevont személyek, egytől egyig erőszakos bủncselekmények miatt töltik jogerős ítéletüket. A megkérdezettek életkora változó volt, 25 évestől 65 évesig minden korosztály képviseltette magát. A kutatás különlegessége, hogy a régebben különleges biztonságú körletként számontartott, mai nevén „hosszú idejű speciális rezsim” nevet viselő körletbe is bebocsátást kaptam, ahol tényleges életfogytiglani büntetésüket töltő fogvatartottakat is bevontam a kutatásba. A kutatásomba bevont személyeket egy bv. intézet pszichológusának segítségével a beszélgetés előtt a körleten kerestem meg, és szóban kérdeztem meg, hogy hajlandóak-e nekem segíteni egy egyetemi kutatásban. Aki hajlandóságot mutatott, azzal négyszemközt a pszichológus irodájában beszélgettem. A strukturált interjú keretében minden fogvatartottnak ugyanazokat a kérdéseket tettem fel, a kérdéssor a családjukra, gyermekkorukra, iskolai éveikre, esetleges kudarcaikra és a baráti körük összetételére fókuszált. (Megjegyzés: Mivel az egyes elektronikus eszközök bevitele a bv. intézet területére korlátozott, így a kapott válaszokat írásban rögzítettem. Az egyes interjúk elején mindig tájékoztattam még egyszer az elítélteket, hogy egy diplomamunkához szükséges kutatásban vesznek részt, aki igényelte, annak elmagyaráztam, hogy mi is az a diplomamunka. Egyes elítélteket meg kellett nyugtatni, hogy nem vagyok álruhába bújt újságíró. Az interjúk elején mindenkinél tapasztalható volt egy kis feszültség, illetve izgalom, de ez egy pár perc elteltével oldódott. Kissé megnehezítette a dolgomat, hogy az állandó jegyzetelés miatt nem mindig tudtam megtartani a szemkontaktust, és ez nehezítette a fogvatartottakkal való asszertív kommunikációt. Zavaró tényező volt még, hogy az iroda ajtaját biztonsági okokból nem zárhattam be, így a folyosón közlekedő többi elítélt néha betekintett, sőt valaki be is lépett az irodába elvonva a meghallgatott figyelmét, és megzavarva ezzel az interjút.) Egy-egy interjú ideje átlagosan 40-45 perc volt, így a kutatás majdnem egy hónapig tartott. Biztonsági okokból előre egyeztetett időpontokban nyertem bebocsátást a körletbe, néha 1 hét is eltelt egy-egy interjú felvétele 
között. Egy adott napon 4-5 emberrel volt lehetőségem beszélgetni.

Személyes tapasztalatok alapján a pártfogoltjaim köréből kikerült korai iskolaelhagyók és lemorzsolódottak körében nincs meg otthon a tanuláshoz alkalmas légkör. Nincs íróasztal, nincs a fiataloknak saját szobája, az egy főre jutó hely nagyon kevés. Sokszor találkozom nagyon zsúfolt körülmények között élőkkel (egy szobában 4-5 vagy több gyermek). A szülők gyakran dohányoznak az ingatlanban, és a gyermek ezt a példát fogja követni. Kvázi nagy lesz az iskola által közvetített és a családi norma közötti szakadék. Szintén sajátos példa, hogy egy-egy fiatal többször is osztályt ismétel általános iskolában, folyamatosan kudarc éri, és ez a kudarc el fog vezetni ahhoz, hogy tanulmányaikat ezek az egyének idő előtt befejezzék, vagy az általános iskola elvégzése után nem tanulnak tovább. Képes-e az iskolai kudarc és az aluliskolázottság egy egyént a "deviáns karrier" felé sodorni?

Kutatásom másik fő célja volt, hogy feltérképezzem, melyek azok az állomások egy ember életében, amelyek döntően befolyásolják az egyént a konform társadalmi szabályok megszegésében. Kíváncsi voltam arra is, hogy az elméleti tézisek, amelyek több évtized, esetleg évszázad óta fennállnak, érvényesülnek-e a fogvatartotti populációból megkérdezettek között, illetve magyarázható-e ezekkel a hipotézisekkel a bűnözés, illetve a deviáns magatartás.

\section{A kutatás hipotézisei}

- $\quad$ Feltételezem, hogy a deviáns tettek elkövetői nagy számban kerülnek ki az alacsony státuszú aluliskolázott családokból.

- Feltételezem azt, hogy a deviáns tetteket elkövető személyek zömmel sokgyermekes családból kerülnek ki.

- Feltételezem azt is, hogy a különböző deviáns tettek tipizálhatóak a szocializációs háttér függvényében.

- Feltételezem azt, hogy a deviáns tettek elkövetőinek a családjában és a kortárscsoportjában is jelen van a deviancia.

- $\quad$ Illetve feltételezem azt is, hogy az erőszakos büncselekmények elkövetői a tett pillanatában alkoholos vagy kábítószeres befolyásoltság alatt álltak.

Az interjúkból kiderül, hogy melyek azok a tényezők, amelyek a deviáns viselkedés felé terelik az egyént. Kutatásom keresztmetszetet ad a deviáns személyek életútjáról, életükben felmerült problémákról és krízisekről. 


\section{A hipotézisek és a kapott eredmények összevetése}

- Feltételezem, hogy a deviáns tettek elkövetői nagy számban kerülnek ki az alacsony státuszú aluliskolázott családokból.

- A feltételezés igazolódott, hiszen az elítéltek nagy száma élt sokgyerekes családban, illetve nyilatkozott arról, hogy szegényes, hányattatott gyerekkora volt.

- Feltételezem azt, hogy a deviáns tetteket elkövető személyek zömmel sokgyermekes családból kerülnek ki.

- A feltételezés igazolódott, hiszen a megkérdezett 25 elítéltből 13-an éltek olyan családban, amiben a gyermekek száma meghaladta a 3 főt.

- Feltételezem azt, hogy a deviáns tettek elkövetőinek a családjában és a kortárscsoportjában is jelen van a deviancia.

- A hipotézis igazolódott, hiszen a 25 megkérdezett közül 15 nyilatkozott úgy, hogy a családjában volt valaki büntetve.

- Feltételezem azt is, hogy a különböző deviáns tettek tipizálhatóak a szocializációs háttér függvényében.

- A hipotézis igazolódott, hiszen az elkövetők nagy száma került ki elszegényedett sorsú családból, illetve volt olyan baráti társasága, amely a deviáns karrier felé sodorta az egyént.

- Feltételezem azt, hogy az erőszakos bűncselekményt elkövetetteket korábban érte valamilyen iskolai kudarcélmény.

- A feltételezés igazolódott, hiszen 14 ember nyilatkozott úgy, hogy érték korábban iskolai kudarcok, amelyek befolyásolták életét.

Kutatásom azt igazolta, hogy a deviancia egyik legföbb gyökere az alacsony iskolai végzettség, a fiatalkorban megélt sorozatos iskolai kudarcélmények és az alacsony társadalmi státusz. Összefüggés fedezhető fel az inadekvát szülői nevelés és a bűnelkövetések között is. Amit egy tanult, józan gondolkodású ember nem tenne meg, azt egy aluliskolázott, szegény, alacsony társadalmi státuszú családban felnövő ember megteszi. Az interjúk azt igazolták, hogy a kvalifikálatlan emberek nem mérik fel tettük következményeit, nem számolnak az esetleges retorziókkal.

Az alacsony iskolai végzettségű emberek problémamegoldó képessége jóval fejletlenebb, mint a magasabb iskolai végzettségűeké, melyek egy-egy váratlan problémahelyzetben erőszakos büncselekmények elkövetéséhez vezethetnek. (PI.: olaszliszkai gyilkosság, alsószuhai gyilkosság stb.) Az alacsony társadalmi státusszal rendelkező egyének nem számolnak azzal, hogy egy esetleges erőszakos bűncselekmény elkövetésével a másik embernek milyen fájdalmat okoznak. Látható az is, hogy az elítélt személyek jelentős hányada a magyar átlagnál jóval nagyobb létszámú családban nőtt fel. Ez azért fontos, mert a jövedelem többfelé oszlik, illetve az édesanya a gondoskodását többfelé kell hogy ossza, így előfordulhat az, hogy amikor a gyermeknek a legnagyobb szüksége lenne 
a szülők gondoskodására, pont akkor nem jut idő a gyerekre, ami bizalmatlanságot okoz, sőt Erik Ericson szerint ez a tényező lelki betegségeket is kiválhat az egyénből. (csot.semmelweis.hu)

Az egyéni szocializáció szempontjából fontos mérföldkő volt a megkérdezettek körében a mikrokörnyezetük. A megkérdezettek többségének családjában és baráti körében is van büntetett előéletű ember. Mivel a szocializáció egy egész életen át zajlik, tudat alatt is átvehetik a bünözői magatartást, hiszen abban élnek, nőnek fel, és ezt ítélik meg helyesnek. A mikrokörnyezet kihat az egyéni értékítéletekre. A legtöbb megkérdezettnek volt valamilyen lelki vesztesége, amit nehezen tudott feldolgozni. Jellemző, hogy még a súlyos, traumatikus esetekben sem fordulnak szakemberhez, pl. közeli hozzátartozó váratlan halála. A poszttraumás stressz képes kiváltani agressziót, ami akár az emberölésig is fajulhat.

Elgondolkodtató, hogy az elítélteknél megjelenik a pozitív jövőkép fogalma, illetve az a gondolat, hogy gondoskodni szeretnének a szeretteikről, illetve újra a régi életüket szeretnék élni. Pozitívként ítélem meg, hogy a fogvatartottak nagy része saját bűnét bevallotta, és tudatában van annak, hogy milyen súlyú dolgot követett el, és hasonló esetnél, ha jelen lenne, akkor közbelépne, és megakadályozná azt, hogy a cselekmény megtörténjen. Az Emilé Durkheim által leírt hipotézissel a mai napig jól definiálható a deviancia. Durkheim a biztonságérzet meggyengülésében látta a deviancia egyik okát. Jelenleg az elszegényedett régiókban élő emberek, akiknek nincs megfelelő jövedelme, és biztonságérzetük csökken, folyamatosan követnek el olyan kisebb-nagyobb bűncselekményeket, melyek a napi megélhetésükhöz szükségesek. Ezek főként vagyonellenes cselekmények. A biztonságérzet meggyengülése vezethet természetesen erőszakos bủncselekményekhez is, például az egyik elítélt kapcsolata a feleségével megromlott, elváltak, majd hajléktalan lett, meggyengült a biztonságérzete, majd brutális kegyetlenséggel végzett a teljes családjával. A szakemberek úgy nyilatkoznak, hogy az elkeseredettség és az anyagi biztonságérzet meggyengülése vezeti az embereket ahhoz, hogy raboljanak, olykor amatőr módszerekkel is. Ma már szociológiai közhely, hogy a családnak milyen fontos szerepe van az egyén szocializációjában. A kutatásom azt igazolta, hogy az általam megkérdezett búnelkövetők jelentős részének rendezetlenek a családi viszonyai. 


\section{Irodalom}

Andorka Rudolf et al. (1974): A deviáns viselkedés szociológiája. Gondolat Kiadó, Budapest.

Anthony Giddens (2008): Szociológia. Osiris Kiadó, Budapest.

Borbíró Andrea et al. (2016): Kriminológia. WOLTERS KLUWER KFT., Budapest.

Bűnügyi Statisztikai Rendszer - bsr.gov.hu

Émile Durkheim (1982): Az öngyilkosság. Közgazdasági és Jogi Könyvkiadó, Budapest.

Hegedűs Judit - Fekete Márta (2014): Korai iskolaelhagyás és a kriminalitás kapcsolata, kezelésének lehetőségei. QALLL Projekt, Budapest.

Hegedűs Judit (2014): Gyermekvédelem az iskolában. In: Jó szülő- e az állam? Gyermek- és ifjúságvédelmi Tanulmányok (4). Rubeus Egyesület, Budapest, 3270343.

MárkusBernadett(2018):Krízishelyzetekhttp://csot.semmelweis.hu/wp-content/ uploads/2018/09/13.-M\%C3\%A1rkus-Bernadett-Kr\%C3\%ADzishelyzetek.pdf elérés 2020. 07. 06.

Oszlánczi, Tímea - Simándi, Szilvia (2013): Rechtlicher Hintergrund des lebenslangen Lernens. In: Viola, Tamasova (szerk.) Quality in the Context of Adult Education and Lifelong Education. Dubnica Technological Institute, Dubnica nad Váhom. 69077.

Vigh József (1998): Kriminológiai alapismeretek. Nemzeti Tankönyvkiadó, Budapest.

Weerman Frank - Bijleveld Katrien (2015): Criminal Behaviour from School to the Workplace. Untangling the Complex Relations Between Employment, Education and Crime. Routeledge, New York, $40 \square 49$. 